\title{
The Application of Maslahah Mursalah in A Mediation Process Between Disputant Parties
}

\author{
Andika Catur Prastyo \\ Institut Agama Islam Negeri (IAIN) Surakarta \\ email: dikawonkaa@gmail.com
}

\begin{abstract}
The purpose of this study is to explore how is the mediation process in the Sragen District Court in Sharia economic disputes. It also seeks to determine the suitability of the mediation process in terms of the Maslahah Mursalah. This research is a field research with a qualitative approach. The data source of this study consists of primary data and secondary data. The location of this study is in Sragen District Court. Data collection techniques in this study were using documentation and interviews. This study shows that the mediation process in Islamic economic disputes is not much different from other disputes. This research also reveals that there is a non-compliance with the existing regulations, i.e that peace which is carried out by the parties occurs outside the court and there is no Peace Act. Based on this, it will lead to a different legal effect.
\end{abstract}

Keywords: Mediation Process, Maslahah Mursalah, Sharia Economic Disputes

\section{INTRODUCTION}

It cannot be denied that Islam is a living guidelines. As a guidelines, the teachings of Islam consist of the rules encompassing every aspect of human life. Generally, the rules can be divided into three parts namely Aqida (creeds), Akhlaq (ethics) and Sharia (law). The first two parts, Aqidah and Akhlaq are constant, while Sharia always changes according to the development of human needs and life. Sharia consist of the social affair and area of worship. The worship is to facilitate man how 
to serve his God (hablum minallah), Whereas muamalah has role for man in dealing with others (hablum minannas). The muamala is what the object of the most extensive that must be excavated by people from time to time, because with the advent of the needs human life to be changed. (Suprayitno Eko, 2005)

Islamic economic is the science which result from a human effort to overcome financial problems in a systemtic manner, so that it build confidence and trust in the truth of Qur'an and Sunnah. Surely people need prevailing norms in general and get recognition in general to prove Islamic economic is also as science. (Sudarsono Heri, 2002).

In today economic development, there have been an expansion of financial institutions operating based on principles of Sharia, like the establishment of Sharia bank, Sharia insurance and other Sharia financial institutions. The establishment of those economic institutions with Sharia principles would certainly continue to open up the possibility to the occurence of disagreement and breach between the parties. (Syukri Eska, 2012)

For muslims in indonesia, Sharia economic disputes is among muamalah problem that needs to be addressed, in order that the harmony and peace of Indonesian Muslim. It is because the Believers are brothers. It is also because the implementation of peace between family and brotherhood should be given higher priority (Syukri Eska, 2012)

Based on Law number 3 year 2006 on the amendment act number 7 in 1989 which has been replaced with act number 50 in 2009 about Islamic court, it is said that the authority who can resolve Sharia economic disputes is the religious court. (Syukri Eska, 2012).

The judiciary institutions is one of dispute resolution that play a role so far. But a verdict rendered a trial that has not yet be able to create satisfiction and justice for both sides to the dispute. Judicial decions tends to satisfy one of the parties and they were not satified with the other parties. (Syahrial Abbas, 2009).

One form of economic dispute resolution that incalcutes competence the religious court is through mediation. Mediation on the court shall take effect as of the issuance regulations in 
indonesia since the supreme court number 1 in 2016 about procedure mediation in a court of law. (Syahrial Abbas, 2009)

Mediation is an alternative dispute resolution that can be used by the parties to resolve a dispute over its third party as a mediator. The principle of mediation is both having win-win solution, so that none of the disputing parties feel discontentment. Mediatin is not only to speed up the solution, but also remove vindictive and firm relationship (Syahrial Abbas, 2009). So, this research is going to address two problems, firstly, how is a mediation process to the Sharia economic dispute number 0938/ Pdt.G/2018/PA.Sr in religious court of Sragen? Secondly, how is the perspective of Maslahah Mursalah on a mediation process with the Sharia economic dispute number 0938/Pdt,G2018/PA.Sr in religious court of Sragen?

\section{LITERATURE REVIEW Mediation}

Mediation is an English term. In literature, there are many definitions of mediation (Gunawan Wijaya, 2001). In the dictionary large Indonesian language (Kamus Besar Bahasa Indonesia), it is said that mediation is given meaning as the process of participating third parties in the resolution of a dispute as an advisor (Kamus Besar Bahasa Indonesia, 1998). According to author, mediation and dispute resolution is a process between two or more parties through negotiations or manner of consensus with the help of the helper who do not have authority to judge. Neutral parties are called a mediator with the assistance and subtantial. Therefore, by this definition, we can say that the essential elements that make up a mediation are (Takdir Rahmadi, 2011):

a. A mediation is the way of settlement by negotiation based on consensus approach or consensus of the parties.

b. The parties asked the other impartial body called a mediator

c. A mediator does not have the authority to judge, however it only help the parties to resolve the decision that can be accepted by the parties. 
The consensus approach or mutual consensus in a mediation process means that everything that is produced in a mediation process should be the result of the agreement of the parties and settlement should be attainable if all parties in a dispute can accept it. (Takdir Rahmadi, 2011).

To integrate the mediation to the next process in court can be one of the effective instruments to reduce the possibility of accumulating case in the court. In addition, to insert mediation process in the justice system can help reinforce and maximize the function of the courts to overcome dispute, besides its work of deciding and judging (Takdir Rahmadi, 2011).

In terms of mediation, a mediator play a role in helping disputant parties in identifying the case, developing option, and deliberating in alternatives that can be offered to the parties to reach an agreement. A mediator, in playing his role, only has right to give advise in order to solve the case. A mediator has no authority with regard to content of the case, but he only keep how the mediation can run well so that it can produce agreement from parties. (Syahrizal Abbas, 2009).

A mediator should be able to find alternatives to solve the disputes. He is not only bound and focus on that which belongs to the parties in the resolution of a dispute. A mediator must be able to offer other solutions, when the parties no longer have any alternatives or when the parties suffer from deadlock in the resolution of disputes. This is where a mediator as the third party shall try to be neutral to assit in resolving the dispute. For that reason, a mediator must be have a number of skill to help and facilitate the parties in the resolution of a dispute. (Syahrizal Abbas, 2009)

\section{Maslahah Mursalah}

Etymologically, the word 'maslahah' is derived from a "salaha" or "salahu" which means good. This word is an antonyms of the "fasada" which means damaged. In KBBI, it is mentioned that al-maslahah convey the meaning of something good and benefits. While the 'maslahah' means uses, good, benefits and interest. (Rachmat Syafi'e, 1999). 
Terminologically, al-maslahah is the benefit desired by God to his servants, in the form of maintaining their religion, preserving people/themselves, preserving their descendants, preserving their mind, and preserving their wealth (Asmawi, 2011). As for preserving wealth with reference to terminological sense, our scholar then make categorization of al-maslahah. In terms of levels, al-maslahah is divided into three: al-dharuriyat, hajiyat, and tahsiniyat. What is meant by al-dharuriyat is that it is maslahah that was conceived by their action and it is necessary for human life in this world, especially those kinds of al-maslahah on religion, soul, understanding, honor themselves/ descent and wealth. What is referred to hajiyat is al-maslahah that was conceived by their action to bring the smoothness, ease, and succes for human life. While tahsiniyat is al-maslahah that was conceived by their action by bringing beauty, modesty of the glory and for human life. (Asmawi, 2011)

Maslahah mursalah is the proposition to establish new expicity which have not been mentioned in the main source of Qur'an and Sunnah, whether it is accepted or rejected. (Imron Rosyadi, 2017)

\section{ANALYSIS AND DISCUSSION \\ Settlement Procedure of Sharia Economic Dispute at the Religious Court in Sragen.}

The settlement of economic case at religios court in Sragen of coursehas been carried out through some procedures, inter alia administrative procedures. It is as have been arranged in book II about Pedoman Pelaksanaan Tugas dan Administrasi Peradilan Negara (Guidelines for Performing Duties and Religious Court Administration).

The procedure as follows (Book II About the Guidelines of Duties and the Admistration of Justice Religion):

1. The litigant party come to religious court with an information board religious courts in Sragen by bringing a lawsuit.

2. The litigant party come to officers of the first table and submit a letter of lawsuit or entreaty, at least 2 (two) copies, added by a number of defendant to the letter of a lawsuit. 
3. Officers of the first table can provide explanation which are deemed necessary with regard to the proposed matter and down payment of the legal costs and written in carte blanche to pay (SKUM). The down payment the legal costs is estimated to be enough to solve the case, which is based on article 182 paragraph (1) HIR or article 90 constitution Republic of Indonesian number 50 in 2009 revision of the second time constitution number of 7 in 1989 about religious court. With notes:

a. For those who are not able, then he is permitted to dispute in prodeo manner. The inability is prooved by attaching a letter from head of urban village.

b. For those who are not able, then downpayment of the case is estimated Rp. 0.00 and is written in the procuration to pay (SKUM) which is based on article 237-245 HIR

c. In the first degree, the parties who are not able or prodeo, should mention the causes to dispute in prodeo in his petitum inside his lawsuits or his letter.

4. The officers of first table hand over a suit or a request to the litigant parties accompanied by a procuration to pay (SKUM) in three copies.

5. The litigant parties hand over letter lawsuits or the letters to pay (SKUM) to the cashier.

6. Cash holders sign a procuration to pay (SKUM), affix the ordinal number of the case and the date of receipt into the procuration to pay (SKUM) and in a lawsuit or entreaty. Cash holders hand over the original copy of procuration to pay (SKUM) to the litigant parties as the basis for down payment of the legal costs to the bank.

7. The litigant parties come to counter in the bank and fill in downpayment slip of legal costs. Filling in the data into bank slip is consistent with (SKUM), that is, the same serial number and the cost of payment. Then the litigant parties submit banks slip that had been filled and deposit money with the same nominal written on the bank slip.

8. After the litigant parties received banks slip that had been 
validated by the services, the litigant parties demonstrate the bank slip and hand over the procuration to pay (SKUM).

9. The cash holder hand over slip bank back to the litigant parties once again. The cash holder, thus, gave the proof of full payment in the procuration to pay (SKUM) and handed back to the litigant parties the original copy, first copy of the procuration to pay (SKUM) and lawsuit and the proposal concerned.

10. The litigant parties hand over both of a lawsuit or entreaty as many as the number of defendant added 2 (two) copies and the first copy of the procuration to pay (SKUM) to the officer of second table. Officers of the second table take note on a lawsuit letter or entreaty in a register concerned and give register number on a lawsuit letter taken from admission number that is given by the cash holder.

11. The officer of second table hand over one copy of the proposals or a lawsuit that has been given registering number to the litigant parties.

12. The registration is done, the litigant parties will be called by bailiff to the trial after an arrangement of the judges council being determined and the day a hearing being settled.

\section{A Mediation Process In Sharia Economic Dispute Number 0938/Pdt.G/2018/PA.Sr Religious Court In Sragen.}

A mediation process in the religious court is as follows firstly, to elect a mediator. This one is conducted by the parties, who will choose a mediator from inside or outside the court. If the parties choose a mediator from within the court, the judge then could not be part of the assembly. (Humaidi, 10 July 2019)

After a mediator was determined, the second step is to gather the two parties in one assembly. Each of parties, whether the plaintiff and defendant, can be deputed by their attorneys. They are put together in an assembly, before the presense of the judge as mediator whose role is to bring reconciliation between parties. (Humaidi, 10 July 2019)

The third step is that, the parties outlines their problems at hand. In this case the parties make clear to the mediator about the 
problems that they have, until the parties understand the nature of the problems, and then they know o evercome it. The mediator is hoped as much as possible to reconcile the parties so that dispute are not continuing and sustaining untill it comes to trial. (Humaidi, 10 July 2019)

Fourthly, a mediator give alternative solutions. A mediator (judge) provides a way out or a solution and the best resolution to both sides. The solution given must not bring disadvantage to either parties, or unfairnes for one of the parties. A solution and the alternative should be received by both parties. (Humaidi, 10 July 2019)

Last, the parties give their conclusion. It means that the parties concerned may provide a respond regarding the peace agreement. Whether they agree make peace or will continue to bring the case to the court. (Humaidi, 10 July 2019)

On May 2018, the Religious Courts in Sragen received a Sharia economic dispute with registered number 0938/ Pdt.G/2018/PA.Sr with the plaintiff was Mr. Fakhruddin Nur S. As the operational director of PT.BPRS Sukowati Sragen. Which in this case delegated by Mr. Catur Danarto as employees of PT. BPRS Sukowati Sragen. Located in Sragen Sukowati, Mojomulyo RT 01 RW 10 Sragen. Then a defendant is Mr. Wagiyo work as enterpreneurs with an address in Sidorejo RT 02 RW 03 Ngrombo, village in the Tangen, Sragen Regency. Which in this case delegated Mr. Hermanu Fatah advocates located office in Sambirejo RT. 003 RW. 001, Banaran, Sambungmacan, Village Sragen.

The problems begin when Mr. Wagiyo as a defendant borrows some money to PT. BPRS Sukowati Sragen. Over time Mr. Wagiyo underwent bad credit, which is injurious to the plaintiff parties namely PT. BPRS Sukowati Sragen. PT. BPRS Sukowati Sragen has the right to carry out the auction of Mr. Wagiyo's collateral if the payment of instalment by the defendant is at stake. In this case, PT. BPRS Sukowati Sragen could be conducting the insurance against the defendant to KPKNL (service station in the wealth of the country and auction) or the plaintiff may bring this case to litigation track. PT.BPRS Sukowati Sragen prefer to 
choose litigation and the case has been submitted on 23 May 2018 to the religious court in Sragen. (Catur Danarto, 10 August 2019)

In the first judge, the parties agreed to conduct a mediation process by appointing a mediator of the court, namely $\mathrm{Mr}$. Humaidi. Based on the mediation report dated 24 July 2018, it is said that implementation of mediation results as follows:

1. That the mediation has been implemented in full on the 24 July 2018, located in the mediation religious court in Sragen attended by both sides, but they have put on their own principle. The mediation does not achieve an agreement.

2. That based on aforementioned details, the mediation did not work well. After interviews were conducted by a writer to the relevant party such as, Mr. Humaidi as a mediator, Mr. Hermanu as the attorney from the defendant and we have given Mr. Catur as power by PT.BPRS Sukowati Sragen, some information that can be retrieved are as follows:

In this case, resolution of Sharia economic dispute No. 0938/ Pdt.G/2018/PA.Sr ended peace although settled outside court. During the process of mediation, a mediator gave recomendation first, to conduct consultation outside the court and agreed by the parties that, the debtor is Mr. Wagiyo a defendant in this matter have been failed to pay off credit to PT. BPRS Sukowati Sragen. With this agreement then PT. BPRS Sukowati Sragen authorizes to take Mr. Catur ended peacefully but no certificate peace. Because peace agreed by the parties not in the scope of Religious Court in Sragen. (Catur Danarto, 10 August 2019).

\section{Analysis of the Implementation of a Mediation Process at the Religious Court in Sragen.}

In this case, a mediation process occurring in court in accordance with the supreme court number 1 year 2016 were successfully done, it will given peace certificate to the parties. It has the same legal power as it was decided. So, when peace certicate is issued, the case could not sued back.

When peace agreement occuring outside the court is in accord to the ordinance of the supreme court number 12016 , chapter 
8 article 36 , the parties concerned may hold certificates peace as evidence that the dispute has been agreed to make peace by attaching the result of an agreement of peace, of which evidence shows the legal relation for every party dispute with the object.

A mediation process at the religious court in Sragen number 0938/Pdt.G/2018/PA.Sr is not much different from mediation process in divorce case. The difference lies only in a stage, which is the problem of identification. After mediator hear an explanation of the parties and the parties' wishes, then the mediator gives alternatives or solutions that can be offered for the parties.

As for advandages obtained from such mediation process is, in terms of time, it can be more effective or not protracted. Then, in terms of costs, it can reduce the legal costs. As for the result obtained by the mediation process is the ultimate result obtained, which is the fairness to both sides. For the principle of mediation itself is the win-win solution.

So, a mediation process towards the Sharia economic dispute number 0938/Pdt.G/2018/PA.Sr generally is the same with a mediation process in divorce case. What make it different from mediation process in divorce case is only on alternatives offered by a mediator after problem of identificationis done. As for benefits obtained from holding mediation process is the effectiveness in terms of the time, the cost and the result.

\section{Analysis of Maslahah Mursalah over a Mediation Process in the Sharia Economic Dispute Number 0938/Pdt.G/2018/PA.Sr}

In this case, the principle used in the process of mediation is win-win solution. As for the purpose of mediation itself, besides minimizing the accumulation of problems, it also seeks to accelerate, to simplify the controversy and to eliminate vengeance and to firm up relationship.

A mediator, as the third party who helps to overcome the problem should not be a impartial. A mediator also must play a role in identifying the problems, then develop options and consider an alternatives that can be offered to the parties for reaching the purpose of the mediation, i.e. peacefulness.

This research has its focus on alternatives offered by a 
mediator to different parties when a mediation process take place. This is exactly what the author means to be included in Maslahah Mursalah at the level of hajiyat. Hajiyat is everything secondary in nature for mankind business which should be fulfilled in his life to avoid undesirable difficulties arising from its absence.

As for the advantages obtained by the parties from the implementation of a mediation process is already in accordance with fiqh rules, that stated that:

\section{درء المفاسد مقدم على جلب المصالح}

Based on fiqh rules above and the requirements for Maslahah Mursalah to happen, if the relations of a mediation process are drawn, it is known that:

1. For Mr. Wagiyo, he benefited as being prevented from execution which is guaranted to PT. BPRS Sukowati Sragen if the treaty of peace is not signed. Then, in terms of time and the fees, it is more effective. Because, if a mediation process is carried out succesfully, it will cut the legal costs. Also in terms of the time, the dispute between the two parties can be solved quickly.

2. As for PT. BPRS Sukowati Sragen, the benefits that it obtained from are the peaceful mediation is that PT. BPRS Sukowati Sragen get its money lent to Mr. Wagiyo guaranted. In addition, those money can be circulated again to maintain the liquidity of PT. BPRS Sukowati Sragen. In terms of time and the legal cost, it is more effective. For if the mediation is succesful, it can reduce the legal costs. Also in terms of the time, the dispute between the two parties can be solved quickly.

In this case, there are three levels of maslahah mursalah, that is: al-dharuriyat, hajiyat, and tahsiniyat. If it is linked with the problem which is currently the focus of writer, it can be mapped as follows:

1. Hajiyat, is the second level of human needs whose fulfilment should be achieved, if difficulties and some of pettiness 
is hoped to be avoided in his life. Although in this case a mediation process has been carried out by the parties with the help of a mediator, and it has reached an agreement to come to terms on the recommendation of the given a mediator in a mediation process, this peace agreement happened outside the court. So, there is no peace certificate issued. Then based on hajiyat, where conducted by way the meeting of the parties with assistance from mediator or commonly called a mediation process. After a mediation process had been done, a mediator gave any recommendations for deliberation. As a result, the parties have agreed to come to terms. The process this mediation is of hajiyat level. So, it's include in a moderate degree of hajiyat. For the mediation process bore a peacefulness that shall prevent the parties from difficulty.

2. Tahsiniyat, is a maslahah conceived in any work or action in order to produce beauty, decency and glory for human life. In this case, if it is associated with what writer had been focussed on, all mediation process had passed and reach a peace agreement. The truce is a form of beautiful relationship and manners that can be maintained for the future. Based on the criteria of tahsiniyat level, this peace agrreement was the best possible output of mediation. For a mediation process and the result of that mediation is peace agreement that can bring any beauty and suavity in a relationship.

\section{CONCLUSION}

Based on an analysis in discussion above, conclusion of this research can be taken as follows:

The implementation of the mediation in the Religious court in sragen especially Sharia economic dispute number 0938/ Pdt.G/2018/PA.Sr generally is not different to the resolution procces through the mediation in divorce case. The difference is only when a mediator is in the stage of problems identification. After he did the stage, then a mediator give alternatives or the solution that can be offered to the parties. As for the benefits obtained from arranging a mediation process is in terms of time it could be more effective or not protracted. Then, in terms of the 
cost, it can reduce the legal costs and in terms of results obtained by the presense of a mediation process is the last result available over is fair to both sides. Because, based on the principles of the mediation it was win-win solution. So, a mediation process in Sharia economic dispute number 0938/Pdt.G/2018/PA.Sr is mainly equal to a mediation process in divorce case. What make it different from the later is that the alternatives offered by a mediator after identification of the problem is done. As for benefit obtained of a tackle in a mediation process in terms of the time, the cost and the results.

As for the mediation process number 0938/Pdt.G/2018/ PA.Sr at the religious court in Sragen that is analyzed by theory of Maslahah Mursalah could be known by the three (3) levels of Maslahah Mursalah, that is al-dharuriyat, al-hajiyat, and altahsiniyat. Thus, there obtained two levels of maslaha that have the correlation between the theory and the practice that occurs field. At the level of al-hajiyat, the process of the mediation itself is of the criteria al-hajiyat. For the mediation process is to prevent the parties from difficulty. As for the level of al-tahsiniyat. The whole process of mediation it self and the result of it is that the peace agreed by the parties. As the result of the achieved agreement, the beauty and suavity are hoped to be around during gathering between parties.

\section{REFERENCES}

Eko, Suprayitno. (2005). Ekonomi Islam Pendekatan Ekonomi Makro Islam dan Konvensional, Yogyakarta: Penerbit Graha Ilmu.

Heri, Sudarsono. (2002). Konsep Ekonomi Islam, Yogyakarta: Ekonisia.

Iska, Syukri. (2012). System Perbankan Syariah Di Indonesia Dalam Perspektif Fikih Ekonomi, Yogyakarta: Fajar Media Press.

Abbas, Syahrizal. (2009). Mediasi dalam Hukum Syariah, Hukum Adat \& Hukum Nasional, Jakarta: Media Grafika.

Gunawan Wijaya. (2001). Alternatif Penyelesaian Sengketa, 
Op.Cit, Jakarta: PT Raja Grafindo Persada.

Tim Penyusun Kamus Pusat Pembinaan dan Pengembangan Bahasa. (1998). Kamus Besar Bahasa Indonesia, Jakarta: Departemen Pendidikan dan Kebudayaan.

Rahmadi, Takdir. (2011). MEDIASI: Penyelesaian Sengketa Melalui Pendekatan Mufakat, Jakarta: Rajawali Press.

Syafe'i, Rachmat. (1999). Ilmu Ushul Fiqh, Bandung: CV. Pustaka Setia.

Asmawi. (2011). Perbandingan Ushul Fiqh, Jakarta: Amzah.

Rosyadi, Imron, "Pemikiran Asy-Syatibi Tentang Maslahah Mursalah", Jurnal Studi Islam, Surakarta, Vol. 14, No. 1

Humaidi, Hakim Pengadilan Agama Sragen, Wawancara, $10 \mathrm{Juli}$ 2019, Jam 13.35-14.15 WIB.

Danarto, Catur, Karyawan PT. BPRS Sukowati Sragen, Wawancara, 19 Agustus 2019, Jam 07.30- 08.00 WIB.

Hermanu, Kuasa Hukum Pihak Tergugat, Wawancara, 8 September 2019, Jam 13.50- 14.20 WIB.

Team, Muamala, “Arti-qawaid-fiqhiyah", https://muamala.net/ retrieved on 29 October 2019 